\title{
Insulin Resistance and Oxidative Stress in the Brain: What's New?
}

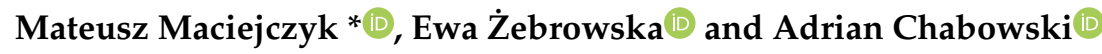 \\ Department of Physiology, Medical University of Bialystok, Mickiewicza 2c Str., 15-222 Bialystok, Poland; \\ ewa.zebrowska13@gmail.com (E.Ż.); adrian@umb.edu.pl (A.C.) \\ * Correspondence: mat.maciejczyk@gmail.com or mateusz.maciejczyk@umb.edu.pl; Tel.: +48-604998854
}

Received: 24 January 2019; Accepted: 14 February 2019; Published: 18 February 2019

\begin{abstract}
The latest studies have indicated a strong relationship between systemic insulin resistance (IR) and higher incidence of neurodegeneration, dementia, and mild cognitive impairment. Although some of these abnormalities could be explained by chronic hyperglycaemia, hyperinsulinemia, dyslipidaemia, and/or prolonged whole-body inflammation, the key role is attributed to the neuronal redox imbalance and oxidative damage. In this mini review, we provide a schematic overview of intracellular oxidative stress and mitochondrial abnormalities in the IR brain. We highlight important correlations found so far between brain oxidative stress, ceramide generation, $\beta$-amyloid accumulation, as well as neuronal apoptosis in the IR conditions.
\end{abstract}

Keywords: brain; insulin resistance; oxidative stress; mitochondrial dysfunction

\section{Introduction}

Nowadays, one of the most significant health problems is an increased incidence of obesity and type 2 diabetes (T2DM) [1-3]. A number of epidemiological and clinical research studies have indicated that overnutrition, low physical activity, as well as many genetic and environmental factors (e.g., chronic stress, xenobiotics, and alcohol abuse) are the main causes of metabolic disorders referred to as "the epidemics of the 21st century" [1-3]. T2DM, the most common type of diabetes mellitus, is generally characterized by chronic hyperglycaemia, hyperinsulinemia, dyslipidaemia, as well as lipotoxicity, which result in progressive deterioration of insulin secretion and insulin action [3-6]. It is widely recognized that insulin resistance (IR) plays a key role in the development of T2DM and its organ-related complications [5,6]. Thus, an explanation of IR pathogenesis is of great clinical significance.

Metabolic disturbances accompanying IR disrupt not only the functioning of liver, muscles and adipose tissue, but also the brain [7-11]. Although for many years the brain has been considered an insulin-insensitive organ, it is now known that insulin acts a critical role in the central nervous system (CNS) participating in neuronal survival, neuroplasticity, memory, and cognitive functions [10,12-14]. Additionally, recent studies have demonstrated that peripheral IR results in loss of the brain function, which indicates strong relationship between metabolic disturbances and cerebral degeneration, cognitive impairment, depression, as well as Alzheimer's disease (AD) $[7,9,15-18]$. It is suggested that one possible common denominator of all these conditions could be chronic oxidative stress [7-9,15-18]. Indeed, in various systemic and genetic diseases, alterations in enzymatic and non-enzymatic antioxidant systems as well as increased oxidation of cellular components are the main factors damaging the brain tissue and promoting cerebral degeneration [19-23]. Nevertheless, the exact role of brain oxidative damage and free radical sources in the brain IR are still unknown. Hence, in this mini review, we provide an overview of the neuronal redox imbalance, oxidative damage, as well 
as mitochondrial dysfunction in IR conditions. Mechanistic insights between the brain IR, ceramide generation, $\beta$-amyloid accumulation, as well as neuronal apoptosis are also presented.

\section{Insulin Role in the Brain}

Insulin, an anabolic peptide hormone, plays a crucial role in the regulation of whole-body glucose homeostasis. Most insulin receptors are located in the target tissues (e.g., liver, skeletal muscles, and adipose tissue), however, their high cellular density has also been reported in the brain, mainly in the areas responsible for regulation of cognitive function, appetite, as well as autonomic activity $[10,12,14,24]$. Interestingly, insulin in the brain may origin not only from pancreatic $\beta$-cells, but also can be synthesized de novo in the neurons and glial cells $[12,14,25]$. Nevertheless, regardless of insulin action/production site, this hormone exerts a similar molecular mechanism both in the brain and in the periphery $[7,26,27]$. As demonstrated in numerous studies, insulin action on the brain includes food intake regulation, feeding behavior, body weight, as well as energy homeostasis $[12,14,24,27]$. These effects may be mediated by two major components of the brain insulin transduction systems: phosphatidylinositol-3-kinase (PI3K)/Akt pathway and mitogen-activated protein kinases/Ras pathway (MAPK/Ras) [12,28]. However, some of insulin actions are specific for the CNS. Indeed, insulin has several neuronal roles: provides neuronal survival, participates in synaptic plasticity, and regulates the brain functioning including memory, cognition, learning, as well as attention $[14,26,29,30]$. It was shown that insulin can modulate neuronal activity through various molecular mechanisms [12,14,31,32]. This hormone affects neurotransmitter receptor density, inhibits norepinephrine and stimulates serotonin reuptake in the CNS synapses [12,33]. It also modulates long-term potentiation (LTP) and long-term depression (LTD) by reducing the amount of AMPA ( $\alpha$-amino-3-hydroxy-5-methyl-4-isoxazolepropionic acid) receptors for glutamate as well as by stimulating the translocation of GABA ( $\gamma$-aminobutyric acid) receptors in the post-synaptic membrane [12,31,32].

It is postulated that insulin may also participate in neuronal glucose metabolism. Although the insulin-regulated glucose transporter GLUT-4 has been identified in the brain [34], it remains an open question whether its translocation is dependent on the insulin action. In recent studies, NIRKO (neuronal insulin receptor knockout) mice showed alterations in glucose-sensing hypothalamic neurons in response to hypoglycemia [35]. Studies conducted on brain GLUT-4 knockout (BG4KO) mice also suggest an important role of GLUT-4 in the regulation of systemic glucose level [36]. Nevertheless, there is no convincing evidence that transport and utilization of neuronal glucose is regulated by the insulin-mediated pathways. However, it should be emphasized that, regardless of the plasma insulin level, cerebral insulin also determines many metabolic effects via modulation of the vagal and sympathetic efferent fibres [37]. These actions include suppression of hepatic glucose production, hepatic triglyceride secretion, as well as lipolysis in the adipose tissue [26,30,37].

\section{Brain Insulin Resistance}

A crucial role in T2DM pathology is attributed to insulin resistance. IR is defined as the lack or decreased response of the target tissues to insulin [38,39]. At the molecular level, IR is caused by a loss/down regulation of the insulin receptors and insulin receptor substrates (IRS-1 and IRS-2), as well as by impairment of the insulin receptor's binding activity [5,38]. Functionally, reduced brain sensitivity to insulin can manifest as alterations in neurite outgrowth, impaired neuroplasticity and disturbances in neurotransmitter's release and uptake $[10,16,40]$. Bearing in mind that many factors contribute to insulin transport to the brain (e.g., lipotoxicity, glucotoxicity, inflammation, and oxidative stress), systemic IR may affect the cerebral insulin signalling as well as lead to impairment of the insulin-induced LTD [16,29,41,42]. Indeed, it has been demonstrated that peripheral IR (or high circulating insulin level) alters the function of the blood-brain barrier (BBB) by reducing the level of endothelial insulin receptors and decreasing the BBB permeability to insulin $[43,44]$. This results 
in the impairment of physiological insulin functions as well as increased BBB permeability to many substances [26,27].

Although many causes of cerebral IR have been proposed to this day, the only confirmed explanation is ceramide accumulation in the brain tissue $[11,16,45,46]$. Ceramide, a compound of amino alcohol sphingosine and a long saturated fatty acid (C:16-C:32), belongs to a large group of biologically active sphingolipids that build cell membranes of neurons and glial cells $[47,48]$. In addition to the structural properties, ceramide participates in the growth, differentiation, proliferation, and aging of these cells $[47,49]$. However, large amounts of this compound are also produced in the liver. It was shown that peripheral IR is associated with an elevated ceramide generation due to the increased supply of fatty acids (FAs) derived from a high fat diet (HFD) [50-52]. Interestingly, ceramide like other neurotoxic lipids passes through the BBB, contributing to the brain IR via liver-brain axis of neurodegeneration $[16,45,46,53]$. Indeed, several studies have indicated that increased ceramide synthesis in the liver associated with diet-induced IR may also mediate cerebral IR $[8,16,41,45,54]$. Interestingly, in an animal model of IR, reduced insulin sensitivity in the brain confirmed by decreased phosphorylation of insulin receptors/substrates as well as downstream insulin signalling ( $\downarrow$ PI3K-Akt pathway) was reported after different periods of HFD administration (i.e., 5-12 weeks) $[9,41,55,56]$. These differences may result from various diet compositions as well as varied animal models used in the experiments [9]. Moreover, ceramide can also be produced in the brain (via de novo synthesis and/or sphingomyelin hydrolysis). Elevated synthesis of neuronal ceramide associated with impaired insulin signalling was observed not only in vitro and in animal models of IR, but also in the brain of IR patients $[8,41,57,58]$.

In physiological conditions, insulin binding of the insulin receptor activates insulin receptor substrate 1 (IRS-1), which in turn promotes PI3K, then Akt, and finally the downstream targets of Akt such as mTOR (mammalian target of rapamycin kinase), GSK3 $\beta$ (glycogen synthase kinase 3 beta), as well as FOXO (forkhead box transcription factors of the class O) $[6,12,59]$. However, in IR patients, insulin transmission is diminished [46,54,60-62]. It was shown that induction of cerebral IR results from ceramide-mediated phosphorylation of IRS-1 and inhibition of PI3K-Akt signalling in the brain [46,54,60-62]. Briefly, ceramide activates several serine-threonine kinases (e.g., c-Jun N-terminal kinases (JNKs) and IKB kinase (IKK)) able to phosphorylate serine and thus inhibits insulin receptors substrates (mainly IRS-1) [46,60-62]. Consequently, ceramide downregulates Akt phosphorylation and kinase activity via induction of protein phosphatase 2A (PP2A) as well as activates interleukin-1 $\beta$ converting enzyme (ICE)-like proteases, resulting in the disruption of insulin signalling pathway and promotion of neuronal apoptosis [16,54,62]. Additionally, it has been demonstrated that ceramide impairs brain cell viability, energy metabolism and mitochondrial activity, and therefore, may mediate neuro-cognitive deficits in IR patients [41,46,54,60-62]. Although mainly long chain ceramide (C24, C36) is able to induce cerebral IR, recent studies indicated that also short-chain ceramide (C2) may alter insulin transmission in the brain [45,54]. Additionally, it was shown that ceramide supresses anti-apoptotic Bcl-2 and inhibits protein kinases B (PKB) and C (PKC- $\alpha)[63,64]$. Ceramide-induced apoptosis, similarly as in the neurodegenerative diseases, may therefore cause cerebral complications of IR $[65,66]$.

Despite the proven role of ceramide's neurotoxic effects in the brain, the pathogenesis of cerebral IR is still not well understood and required further research.

\section{Alzheimer's Disease as a Type 3 Diabetes}

$\mathrm{AD}$, the most common type of dementia, is characterized by gradual decline of memory and cognitive functions associated with accumulation of neurotoxic amyloid- $\beta(A \beta)$ in the forebrain $[67,68]$. The phenotypic hallmark of AD also includes intraneuronal deposition of hyperphosphorylated and polyubiquitinated proteins (mainly tau protein) resulting in accumulation of neurofibrillary tangles (NFTs), neuronal loss, gliosis, dystrophic neuritis, as well as neuropil threads $[10,67,68]$. Although the exact causes of the disease are still not well understood, many studies indicate disturbed insulin 
signalling in the AD brain $[10,18,29,69,70]$. Nevertheless, alterations in the cerebral glucose utilization as well as defects in insulin transmission have been mainly reported in the early stages of Alzheimer's disease [61,71,72]. De la Monte et al. [58,73] observed decreased mRNA/protein expression of insulin receptors, insulin-like growth factors (IGF1 and IGF2), IRS1, PI3K/Akt as well as increased GSK-3 $\beta$ level in the post-mortem brains from AD patients. Interestingly, the observed changes were inversely correlated with neuropathological features of $\mathrm{AD}$, which indicates the relationship between impaired insulin signalling and progression of the disease [70]. Deficits in insulin/IGF receptor binding were also noted in the cerebrospinal fluid (CSF) of AD patients [58,70,74].

It has been demonstrated that many abnormalities in AD pathology (e.g., increased tau phosphorylation, disturbances in energy metabolism, neuronal growth as well as synaptic plasticity) may result from impaired insulin signalling in the CNS. Indeed, in AD brain, cerebral insulin/IGF resistance leads to increased activation of GSK-3 $\beta[70,75,76]$. It was shown that stimulation of GSK-3 $\beta$ promotes hyperphosphorylation of tau protein, and therefore induces tau misfolding and fibril aggregation in the brain [70,75]. However, tau hyperphosphorylation is also mediated by up regulation of cyclin-dependent kinase 5 (cdk-5) and inhibition of PP2A [73,77]. Additionally, also A $\beta$ peptides disrupt insulin transmission in $\mathrm{AD}$ brain by competing with insulin and/or reducing the binding affinity of insulin to its receptor [73,78,79]. It was shown that $\mathrm{A} \beta$ peptides directly interferes with PI3 kinase activation of Akt, leading to GSK-3 $\beta$ induction and associated tau pathology $[73,78,79]$. Finally, in AD brain, decreased insulin signalling through IRS, PI3K and Akt may also be linked to a loss in neuronal/oligodendroglial survival, cell growth, as well as neuroplasticity [61,73]. Since abnormalities in AD brain are characterized by both insulin resistance and insulin deficiency, it is proposed that Alzheimer's disease could be referred as "brain diabetes" or "type 3 diabetes" [58,67,80].

The crosstalk between impaired insulin transmission and cognitive impairment may also be evidenced by benefits from intranasal insulin administration in patients with AD. Indeed, several studies have demonstrated that intranasal insulin treatment improves cognitive performance, attenuates hyperphosphorylation of tau protein, as well as ameliorates microglial activation in individuals with an early stage of AD [81-84].

\section{Oxidative Stress in the Brain Insulin Resistance}

The latest clinical studies have shown a strong relationship between whole body IR and higher incidence of neurodegeneration, dementia, depression, and mild cognitive impairment $[7,9,15-18,46]$. Although some of these abnormalities could be explained by chronic hyperglycaemia, hyperinsulinemia, dyslipidaemia, and/or prolonged whole body inflammation, the key role is attributed to the mitochondrial dysfunction and brain oxidative stress [7-9,15-18,85-87]. Indeed, oxidative stress is the main pathological factor responsible for metabolic abnormalities (e.g., disturbances in glucose and lipid metabolism), as well as cerebral degeneration, aging, and CNS injury $[6,7,23,88]$. Generally, oxidative stress is defined as an imbalance between the production of reactive oxygen (ROS) and nitrogen (RNS) species as well as the efficiency of enzymatic (e.g., catalase, glutathione peroxidase, superoxide dismutase) and non-enzymatic (e.g., reduced glutathione (GSH), uric acid) antioxidative systems $[89,90]$. Redox abnormalities in favour of oxidative reactions result in oxidative damage, wherein both proteins, lipids and nucleic acids are oxidized. The effect of free radical interactions may be damage to cell membrane or mitochondria, accumulation of oxidatively modified proteins, as well as the formation of genetic mutations in DNA/RNA [91]. High reactivity of free radicals results from their very short half-life as well as the ability to give/attach valence electrons, which participate in biochemical reactions. The resulting by-products of oxygen metabolism (including newly generated free radicals) react with all the encountered biomolecules $[90,91]$. Thus, the consequences of the ROS/RNS activity can occur at considerable distances from the site of the primary oxidative damage [92]. It is well known that oxidative modification products may disrupt cell metabolism and signalling, in particular increasing the production of pro-inflammatory cytokines, modifying gene expression, and promoting cell death by apoptosis and necrosis [90,91]. 
Under IR conditions, disturbances in enzymatic and non-enzymatic antioxidants as well as the increased content of oxidative modification products have been reported in serum/plasma [93-97] as well as liver, muscles, adipose tissue, and brain tissue [9,86,93,96-99]. However, of all body organs, the brain is particularly sensitive to the free radical attack $[100,101]$. Constituting less than $2 \%$ of the body, the brain uses over $20 \%$ of the oxygen delivered to the organism. Phospholipids of cerebral cell membranes are also enriched in polyunsaturated fatty acids (PUFAs) which, together with the low activity of brain antioxidant enzymes and the high content of pro-oxidant metal ions (e.g., $\mathrm{Fe}^{2+}$, $\mathrm{Cu}^{2+}, \mathrm{Co}^{2+}$, and $\left.\mathrm{Cr}^{2+}\right)$, make the brain very vulnerable to oxidative stress $[93,100,101]$. Therefore, this is not surprising that in the IR brain, overproduction of ROS leads to oxidative damage associated with higher cell membrane permeability, ATP depletion, and accumulation of protein aggregates. One of the deleterious consequences of lipid and protein oxidation may also be an induction of pro-inflammatory enzymes and thus stimulation of the brain inflammation [7-9,67,99,102,103]. The abovementioned, all together, may predispose neurodegeneration and/or neuronal apoptosis (Figure 1).
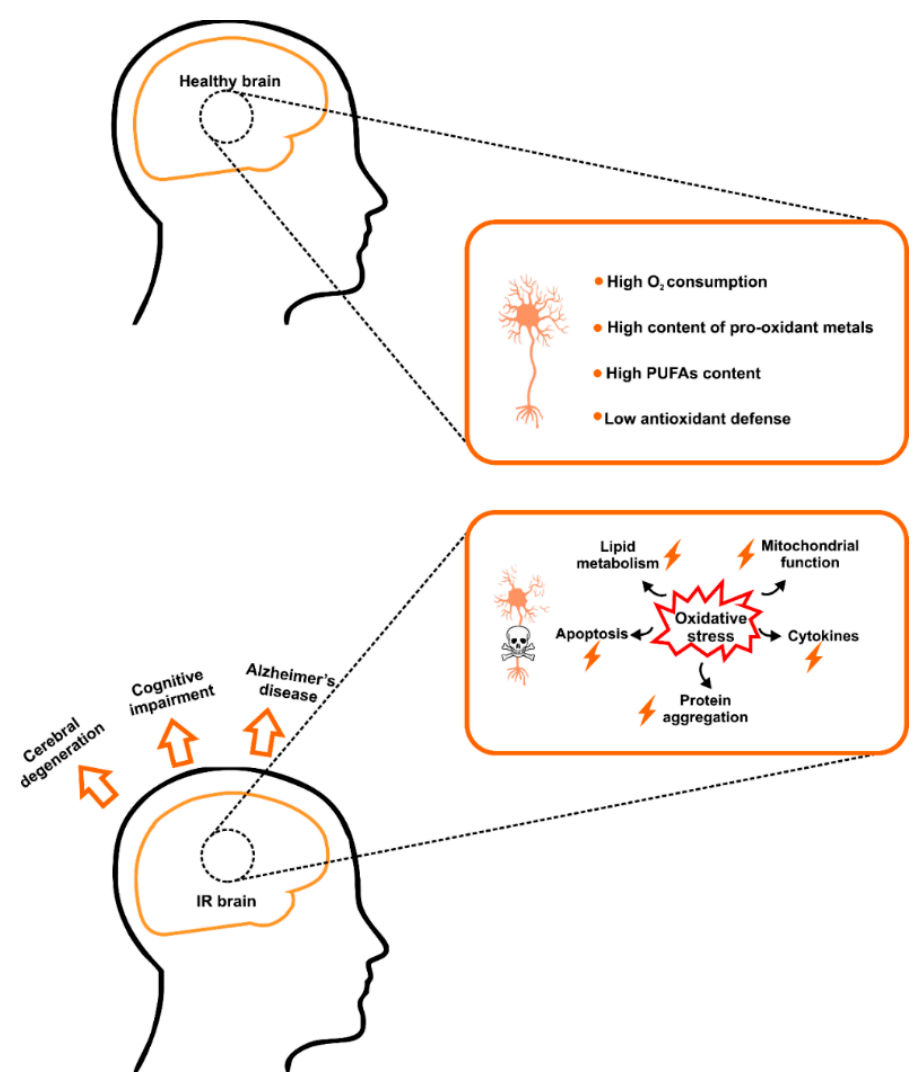

Figure 1. The brain as a specific target for insulin resistance and oxidative stress. The brain is particularly sensitive to the free radical attack due to its increased oxygen consumption, limited antioxidative mechanisms, as well as high levels of polyunsaturated fatty acids (PUFAs). In IR brain, overproduction of reactive oxygen species (ROS) leads to oxidative damage associated with ATP depletion, activation of pro-inflammatory cytokines, accumulation of protein aggregates, as well as neuronal apoptosis. Abbreviations: IR, insulin resistance; PUFAs, polyunsaturated fatty acids.

As demonstrated in recent studies, increased efficiency of enzymatic (e.g., $\uparrow$ catalase, $\uparrow$ superoxide dismutase, $\uparrow$ glutathione peroxidase, $\uparrow$ glutathione reductase) and non-enzymatic ( $\uparrow$ uric acid) brain antioxidants observed in IR conditions should be considered as an adaptive reaction in response to enhanced free radical production $[55,93,104,105]$. Indeed, it is well-known that strengthening the antioxidant barrier is the basic protective mechanism against the ROS-mediated injury [106]. However, such changes have not been observed in the cerebral glutathione (GSH) level $[55,107,108]$. Interestingly, lowered GSH levels (with a simultaneous increase in GSSG (oxidized glutathione) levels) 
were reported not only in the IR brain, but also in patients with AD, Parkinson's disease, multiple sclerosis, amyotrophic lateral sclerosis and Huntington's disease [55,107-112]. It is postulated that disturbances in glutathione metabolism may result in the impairment of cerebral functioning in both IR and neurodegenerative diseases $[110,111]$. This fact is not surprising because GSH is the most important of the brain's antioxidants $[112,113]$. This compound, in addition to the antioxidant properties, also participates in the regeneration of other free radical scavengers (e.g., vitamins $C$ and $E$ ), regulates gene expression (including the insulin signalling proteins), maintains sulfhydryl groups (-SH) in the reduced state, as well as affects proliferation, differentiation and neuronal apoptosis [109,111,112,114]. However, also advanced glycation end products (AGE, products of glycation and oxidation by reducing sugars) are an important link between IR and cerebral degeneration [115-117]. It has been demonstrated that the accumulation of protein aggregates leads to morphological changes in the brain tissue and increases the production of pro-inflammatory cytokines and chemokines [115,118-120]. Moreover, it has been shown that AGE may increase production of free radicals by inducing the activity of NADPH oxidase (NOX), which is the main source of ROS in neurons and glial cells [116,121,122]. Indeed, the increased AGE content was demonstrated in patients with IR and neurodegenerative diseases, especially in the hyperglycemic conditions [93,119,120,123,124]. Nevertheless, different cerebral structures are characterized by varied sensitivity to the redox imbalance and oxidative stress [93,102]. As demonstrated in recent studies, the cerebral cortex of IR rats is more strongly affected by oxidative stress than the hypothalamus [93]. The dissimilar response of the brain structures may result from changes in mitochondrial bioenergetics as well as distinctive ability to accumulate pro-oxidant metal ions (mainly $\mathrm{Fe}^{2+}$ and $\mathrm{Cu}^{2+}$ ) $[125,126]$.

\section{Metabolic Disturbances as a Link between Brain Insulin Resistance, Oxidative Stress and Neurodegeneration}

According to the current state of knowledge, metabolic disorders accompanying peripheral IR are thought to induce neuronal oxidative stress. It is well established that in insulin-sensitive peripheral tissues, excessive intracellular lipid accumulation (mainly diacylglycerol (DAG) and ceramide) inhibits insulin signalling pathways leading to decreased glucose utilisation $[5,38,127,128]$. In these tissues, the production of pro-inflammatory cytokines (e.g., IL-1 $\beta, \mathrm{IL}-6, \mathrm{TNF}-\alpha$ ) also increases, which activates several serine-threonine kinases (e.g., JNK and IKK) phosphorylating the serine residues of the insulin receptor substrate 1 (IRS-1), which in turn blocks the insulin signalling proteins (e.g., PI3-K-Akt, GSK3 $\beta$, and AMPK) [6,129-131]. Additionally, it has been demonstrated that the toxic effects of hyperglycaemia are associated with the activation of the polyol/protein kinase C (PKC) pathway, autooxidation of glucose, as well as accumulation of AGE $[5,128,132,133]$, whereas the excessive availability of FAs inhibits glycolysis and impairs the functioning of the mitochondrial respiratory chain (mETC) [134-137]. All of these factors result in the activation of NFKB (nuclear factor kappa B) pathway [138-140]; and therefore, both lipotoxicity and glucotoxicity are an important source of free radicals and inflammation. Indeed, it is beyond question that NF- $\mathrm{kB}$ signalling plays a key role in regulating the amount of ROS/RNS in the cell $[141,142]$. Considering that the brain is particularly sensitive to the redox abnormalities, peripheral oxidative stress can affect the induction of neuronal oxidative stress (Figure 2). Especially, it is promoted by the increased BBB permeability under IR/hyperglycaemic conditions. Interestingly, Maciejczyk et al. [93] observed a positive correlation between the brain oxidative damage and the HOMA-IR (homeostasis model assessment of insulin resistance) index, which points at the involvement of peripheral IR in the development of neuronal oxidative stress.

Due to the fact that ceramide mediates IR and can cross the BBB, there is a relationship between peripheral IR and cerebral degeneration $[8,45,46]$. However, it has been demonstrated that exposure to short-chain ceramide results not only in neuronal IR, but also inflammation, mitochondrial dysfunction, and free radical-mediated damage $[8,16,45,70,143]$. Indeed, it has been proven that the increase in ceramide level intensifies the activity of caspase-3 and caspase-8 (via $\downarrow$ insulin signalling 
and $\uparrow$ inflammation), which leads to the increased production of ROS and induction of oxidative stress $[65,144,145]$. This mechanism is also postulated in the IR brain (Figure 3).

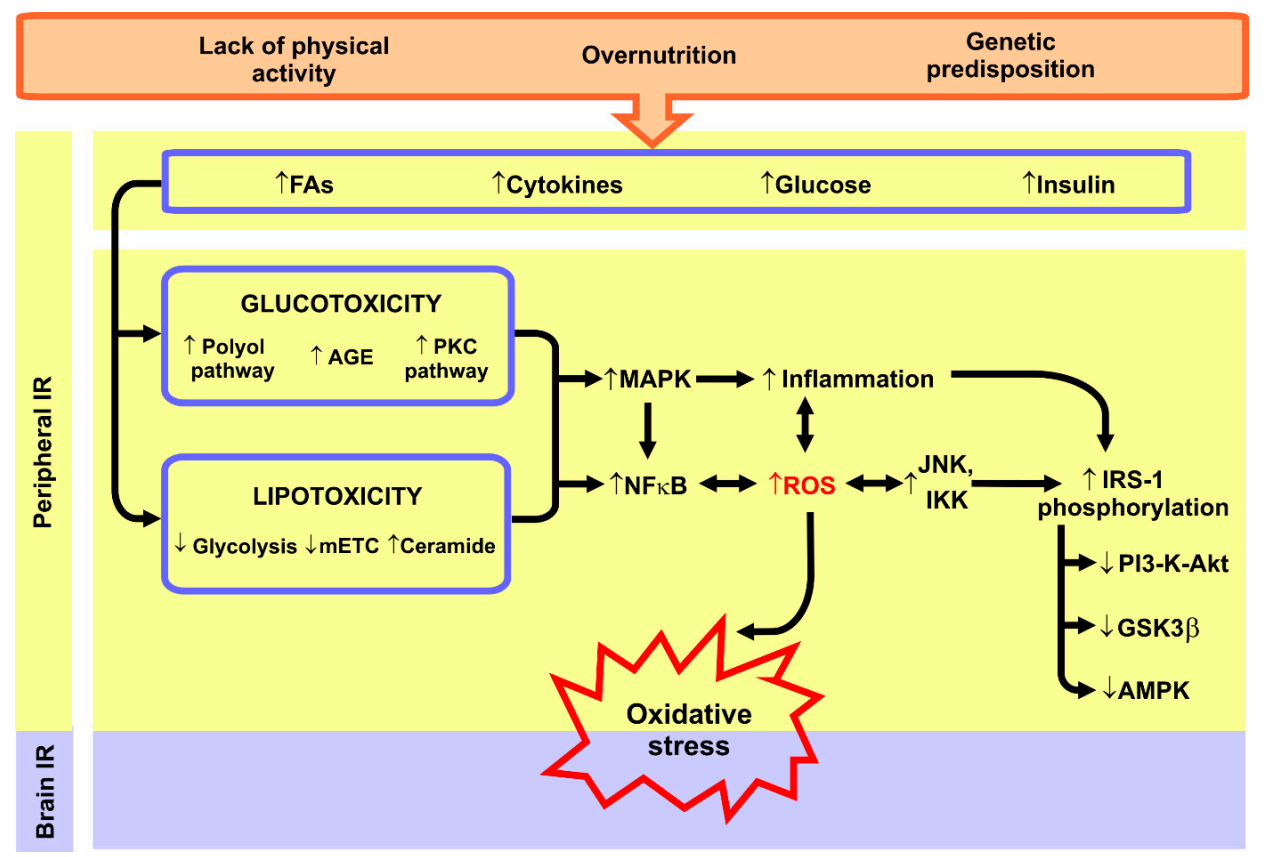

Figure 2. Metabolic disturbances in peripheral insulin resistance as a source of brain oxidative stress. Under insulin resistance (IR) conditions, enhanced plasma fatty acids (FAs), hyperglycaemia, and hyperinsulinemia promote glucotoxicity and lipotoxicity (especially ceramide accumulation) leading to the activation of nuclear factor $\mathrm{\kappa B}(\mathrm{NF} \kappa \mathrm{B})$ and pro-inflammatory signalling (e.g., MAP-kinases). Not only does it intensify the inflammation, but it also increases the formation of reactive oxygen species (ROS). Abbreviations: AGE, advanced glycation end products; AMPK, AMP-activated protein kinase; FAs, fatty acids; GSK3 $\beta$, glycogen synthase kinase 3 beta; IKK, IKB kinase; IRS-1, insulin receptor substrate 1; IR, insulin resistance; JNK, c-Jun terminal kinase; MAPK, mitogen-activated protein kinases; mETC, mitochondrial electron transport chain; $\mathrm{NF} \kappa \mathrm{B}$, nuclear factor $\kappa \mathrm{B}$; $\mathrm{PKC}$, protein kinase C; PI3-K-Akt, phosphatidylinositol 3-kinase/Akt; ROS, reactive oxygen species.

However, ceramide can also enhance formation of amyloid $\beta$-peptides through posttranslational stabilization of $\beta$-secretase (BACE1), which stimulates proteolytic modifications of $A \beta$ precursor protein (APP) $[60,61,146,147]$. It is well known that deposition of $A \beta$ protein plays a key role in the neurodegeneration in AD. Nevertheless, increased $A \beta$ level was also reported in the IR patients $[67,148]$. Interestingly, a key mediator of $A \beta$-neurotoxic effects may not be directly related to ceramide but rather to oxidative stress (Figure 3 ). The resulted $A \beta$ peptide highly up-regulates NADPH oxidase (NOX) generating a large amount of superoxide anions $\left(\mathrm{O}_{2}^{-}{ }^{-}\right)$associated with GSH depletion, mitochondrial abnormalities, and oxidation of lipids, proteins, and nucleic acids $[46,60,61,146]$. Indeed, a high activity of pro-oxidant enzymes: NOX and xanthine oxidase $(\mathrm{XO})$ was recorded in IR brain, which dramatically enhances consumption of oxygen (during respiratory burst in mitochondria), and therefore, may further induce cytokine activation in the brain inflammatory cells [93,149-151]. It has also been demonstrated that in the IR brain expression of cytokines (e.g., IL-1 $\beta$, IL-6, TNF $\alpha$ ), chemokines, and pro-inflammatory enzymes (e.g., COX-2 and iNOS) is significantly increased, not only in the hypothalamus and cerebral cortex, but also in other brain structures such as cerebellum, amygdala and hippocampus $[28,102,152-154]$. It has also been evidenced that IL-1 $\beta$ reduces glucose transport into the cells by inhibiting the expression of IRS-1, whereas TNF $\alpha$, IL- 6 and IL-1 $\beta$ lead to the activation of JNK kinase and $\kappa B$ kinase inhibitor (IKK $\beta$ ), which decreases brain insulin sensitivity $[55,102,152,155]$. Interestingly, also AGEs have been shown to stimulate pro-oxidant and pro-inflammatory signalling (e.g., NFkB, JNK, and MAPK), as well as directly enhance NOX activity, which corresponds to ROS 
overproduction as well as neuronal inflammation [102,116,119]. Additionally, higher formation of ROS can also activate cerebral sphingomyelinases (SMases), which hydrolyse membrane sphingomyelin and further increase the production of ceramide in the brain $[46,60,61]$. Consequently, oxidative stress may be a critical mediator of ceramide's neurotoxic effects, which partially explains the relationship between the brain IR and neurodegeneration in Alzheimer's disease (Figure 3).

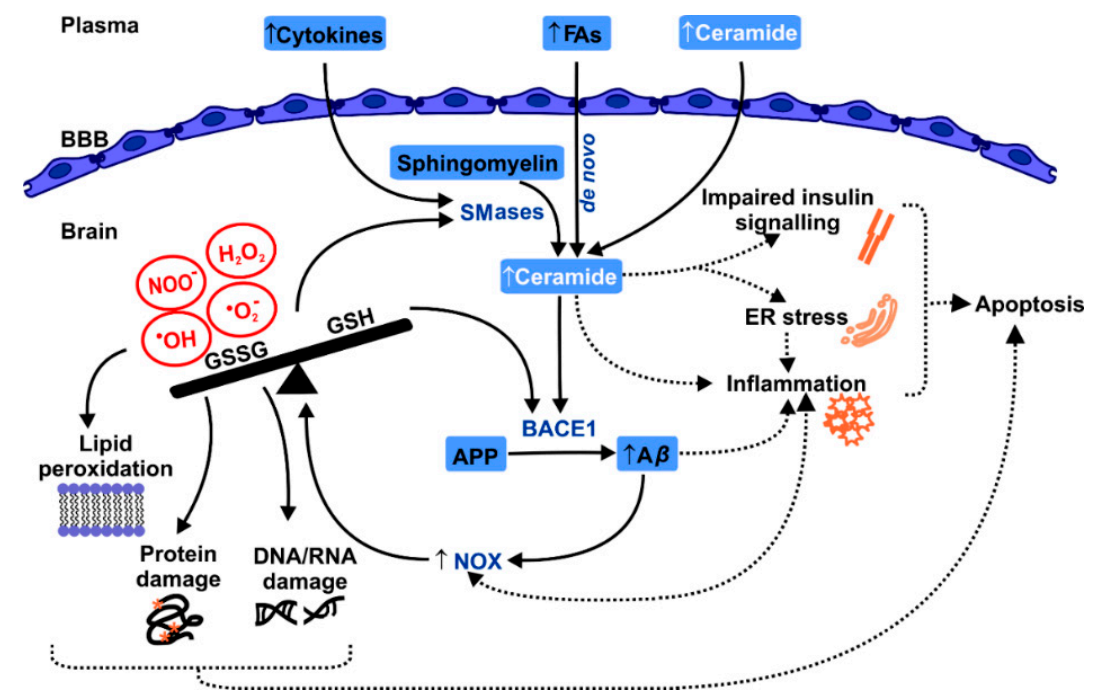

Figure 3. Crosstalk between ceramide, oxidative stress, and the brain insulin resistance. Ceramide plays a key role in the induction of brain IR. Peripheral IR is associated with an elevated ceramide generation. Ceramide like other neurotoxic lipids can pass through the blood-brain-barrier (BBB), contributing to the brain IR via liver-brain axis of neurodegeneration. In IR brain, ceramide can induce neuronal apoptosis and, similarly to Alzheimer's disease, accumulation of amyloid $\beta$-peptides (A $\beta)$. However, a key mediator of $A \beta$-neurotoxic effects may not be the ceramide but rather oxidative stress. It has been demonstrated that $\mathrm{A} \beta$ induces activation of NADPH oxidase (NOX) associated with glutathione (GSH) depletion, lipid and protein oxidation, disturbances in glucose metabolism, as well as mitochondrial abnormalities. Abbreviations: $\mathrm{A} \beta$, amyloid $\beta$-peptides; $\mathrm{APP}, \mathrm{A} \beta$ precursor protein; BBB, blood-brain-barrier; BACE1, $\beta$-secretase; ER, endoplasmic reticulum; FAs, fatty acids; GSH, reduced glutathione; GSSG oxidised glutathione; NOX, NADPH oxidase; SMases, sphingomyelinases.

As shown in recent studies, also excessive levels of circulating FAs may increase the formation of intracellular ROS in the brain [156-159]. Interestingly, in these conditions, ROS overproduction results in neuronal toxicity by inducing neuroinflammation and endoplasmic reticulum (ER) stress $[16,54,157]$. It is suggested that FAs can pass through the BBB and enhance de novo synthesis of ceramide, which can explain the induction of brain IR as well as neuronal redox imbalance (Figure 3).

\section{Mitochondrial Abnormalities in the Brain Insulin Resistance}

Mitochondria play a vital role in energy homeostasis of the cell. In addition to the bioenergetic processes, they also participate in insulin signalling, cell death/survival control, as well as are the main site of ROS generation in the cell during respiratory reactions in mETC. Therefore, it is not surprising that mitochondrial abnormalities are highly related to the development of peripheral IR $[5,134,160,161]$. It is well known that in IR/obese patients, excessive supplies of glucose and FAs contribute to the higher formation of mitochondrial ROS (mROS) produced as by-products of mETC [136,137,160]. Under these conditions, particularly large amounts of superoxide anion $\left(\mathrm{O}_{2}{ }^{\bullet}\right)$ are formed, which not only oxidizes cell components but also inhibits the activity of glycolytic enzymes [160]. Additionally, the results of recent studies indicate a pivotal role of mitochondrial dysfunction also in the brain IR (Figure 4) $[9,28,103,135]$. In fact, decreased activity of brain mETC, reduced mitochondrial respiration, mutations in mitochondrial DNA (mtDNA), as well as disturbances in mitochondrial fusion and fission 
were observed in vitro and in animal models of IR $[9,28,103,135,162]$. This results not only in reduced ATP synthesis, decreased $\mathrm{O}_{2}$ consumption and $\mathrm{CO}_{2}$ generation, but also in mROS overproduction and associated redox imbalance [162-164]. Furthermore, it was shown that in IR brain, enhanced mROS levels lead to neuronal apoptosis observed as higher expression of pro-apoptotic proteins (Bax, Bad, Bak), lower levels of anti-apoptotic Bcl-2, as well as caspases signalling activation $[9,28,103,135]$. Indeed, it has been demonstrated that cytochrome c (cyt c) is released following mitochondrial swelling and forms the complex with APAF1 (apoptotic protease activating factor 1), which stimulates the caspase cascades in the brain $[7,9,28]$ (Figure 4).

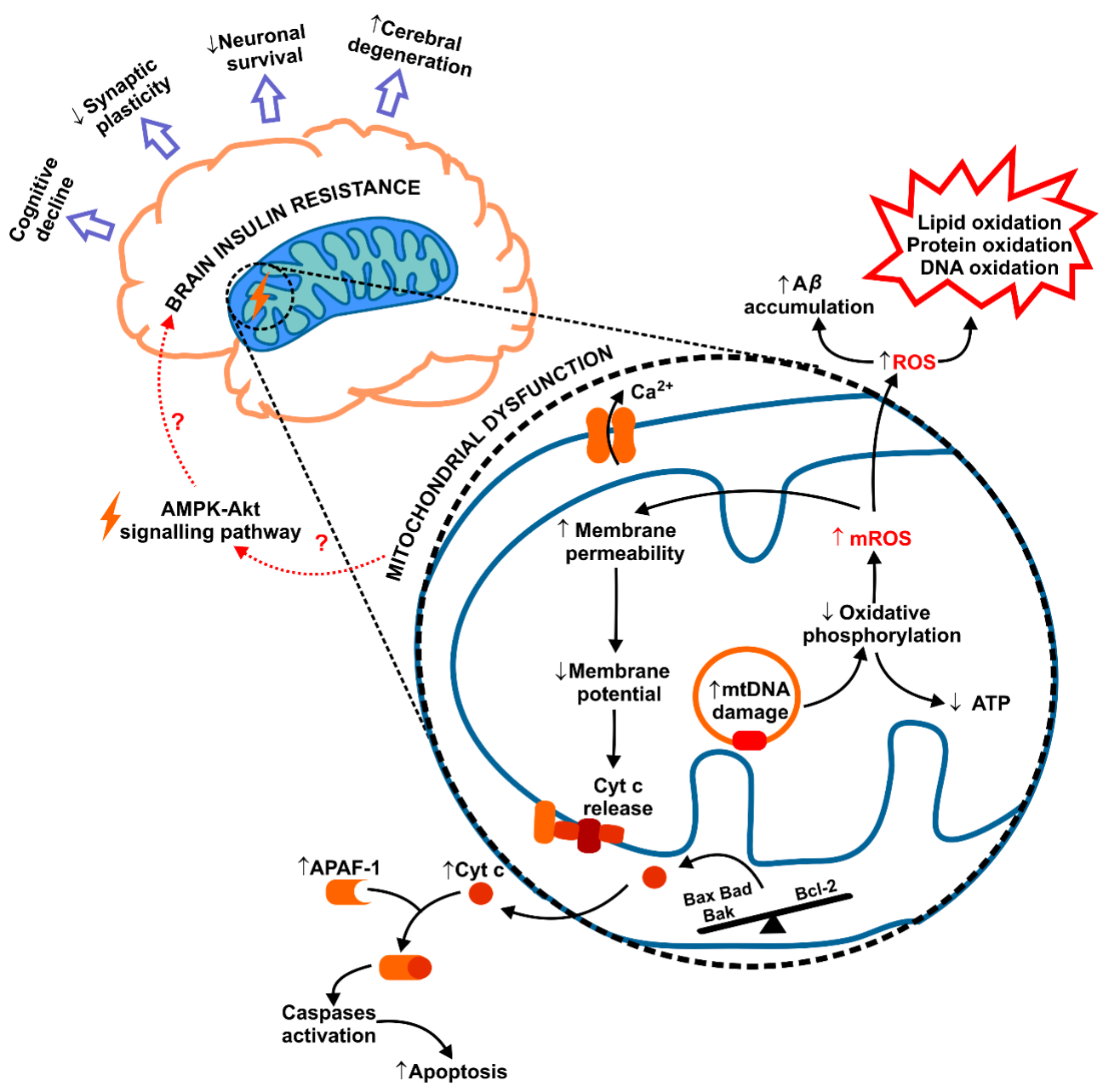

Figure 4. Mitochondrial dysfunction in brain insulin resistance. The results of recent studies indicate the role of mitochondrial abnormalities in the brain IR. Increased production of mitochondrial ROS (mROS), cytochrome c release, as well as functional and ultrastructural changes of mitochondria have been confirmed in IR brain. Interestingly, brain mitochondrial dysfunction and A $\beta$ accumulation may be responsible for disturbances in apoptosis, synaptic plasticity, cognitive decline, and cerebral degeneration in IR patients. Abbreviations: $A \beta$, amyloid $\beta$-peptides; APAF1, apoptotic protease activating factor 1; $\mathrm{BAD}, \mathrm{Bcl}-2$-associated death promoter; $\mathrm{BAK}, \mathrm{Bcl}-2$ homologous antagonist killer; BAX, Bcl-2-associated X protein; cyt c, cytochrome c; mROS, mitochondrial ROS; mtDNA, mitochondrial DNA; ROS, reactive oxygen species.

Several studies reported that mROS overproduction enhances the accumulation of amyloid $\beta$-peptides and induces oxidative damage to proteins, lipids and nucleic acids in the IR brain $[16,153$, $165,166]$. Interestingly, also the decrease in dendritic spine density and long-term potentiation (LTP) processes were linked to the mitochondrial abnormalities in the IR brain [41,98,167-169]. Thereby, the imbalance in mitochondrial dynamics and malfunction of brain mitochondria can be responsible 
for both disturbances in neuronal apoptosis, as well as synaptic plasticity, cognitive decline, and cerebral degeneration in the IR brain $[153,165,166]$ (Figure 4). Interestingly, in the animal model of Alzheimer disease, mitochondrial abnormalities and the deposition of $\mathrm{A} \beta$ peptides are dependent on a degree of cognitive impairment in AD transgenic mice [165]. A similar relationship is also postulated in the IR brain.

It has been also demonstrated that the pharmacological treatment such as anti-diabetic drugs (e.g., biguanide, peroxisome proliferator-activated receptor gamma (PPAR $\gamma$ ) agonist, sodium-glucose co-transporter 2 (SGLT-2) inhibitors), hormone therapy (e.g., glucagon-like peptide-1 (GLP-1) and glucose-dependent insulinotropic polypeptide (GIP)), and antioxidant supplementation (e.g., $\mathrm{N}$-acetyl-L-cysteine (NAC), $\alpha$-lipoic acid (ALA)) could improve not only the whole body metabolic parameters but also the brain's insulin sensitivity and its mitochondrial function $[9,98,163,170,171]$. Interestingly, similar benefits were also observed in patients with AD [172-174]. However, only few reports indicate that neuronal mitochondrial damage is associated with impaired insulin signalling pathways (e.g., AMPK-Akt) [42], and thus, with induction of the brain IR. Indeed, there is no convincing evidence that the mitochondrial dysfunction predisposes to the induction of the brain IR, and therefore, further investigation is needed to achieve a better understanding of IR pathogenesis in the brain.

\section{Conclusions}

Several studies demonstrated that brain IR is inextricably linked to oxidative stress associated with accumulation of ceramide and protein aggregates, activation of pro-inflammatory cytokines, mitochondrial dysfunction, as well as neuronal apoptosis. It is believed that ROS overproduction occurs due to metabolic abnormalities accompanying peripheral IR and with an impaired mitochondrial activity in the IR brain. Recent studies have also shown that oxidative stress enhances the accumulation of amyloid $\beta$-peptides as well as decreases in dendritic spine density and long-term potentiation (LTP) in the IR brain. Therefore, redox imbalance may play a key role in cerebral degeneration, cognitive impairment, and increased incidence of Alzheimer's disease in IR patients. Although several studies found the relationship between neuronal oxidative stress and the brain IR, it remains unclear whether redox imbalance is a primary cause of brain IR. We must not ignore the fact that the brain oxidative stress may also be the consequence of peripheral/brain IR. Hence, further studies are needed to better understand the role of oxidative stress in the IR brain as well as indicate the benefits of the use of antioxidant supplements.

Funding: This work was supported by the Medical University of Bialystok, Poland (Grant No. N/ST/ZB/18/ 012/1118, N/ST /ZB/18/009/1118) and National Science Centre, Poland (Grant No. 2018/29/N/NZ4/02011).

Conflicts of Interest: The authors declare no conflict of interest.

\section{References}

1. Tian, X.; Yan, C.; Liu, M.; Zhang, Q.; Liu, D.; Liu, Y.; Li, S.; Han, Y. Obesity and insulin resistance. PLoS ONE 2017. [CrossRef]

2. Barazzoni, R.; Gortan Cappellari, G.; Ragni, M.; Nisoli, E. Insulin resistance in obesity: An overview of fundamental alterations. Eat. Weight Disord. 2018, 23, 149-157. [CrossRef] [PubMed]

3. Matczuk, J.; Zalewska, A.; Łukaszuk, B.; Knaś, M.; Maciejczyk, M.; Garbowska, M.; Ziembicka, D.M.; Waszkiel, D.; Chabowski, A.; Zendzian-Piotrowska, M.; et al. Insulin Resistance and Obesity Affect Lipid Profile in the Salivary Glands. J. Diabetes Res. 2016, 2016. [CrossRef] [PubMed]

4. Bastien, M.; Poirier, P.; Lemieux, I.; Després, J.P. Overview of epidemiology and contribution of obesity to cardiovascular disease. Prog. Cardiovasc. Dis. 2014. [CrossRef] [PubMed]

5. Taylor, R. Insulin resistance and type 2 diabetes. Diabetes 2012, 61, 778-779. [CrossRef]

6. Yazıc1, D.; Sezer, H. Insulin resistance, obesity and lipotoxicity. In Advances in Experimental Medicine and Biology; Springer: Cham, Switzerland, 2017; Volume 960, pp. 277-304.

7. Pugazhenthi, S.; Qin, L.; Reddy, P.H. Common neurodegenerative pathways in obesity, diabetes, and Alzheimer's disease. Biochim. Biophys. Acta Mol. Basis Dis. 2017. [CrossRef] 
8. De La Monte, S.M.; Longato, L.; Tong, M.; Wands, J.R. Insulin resistance and neurodegeneration: Roles of obesity, type 2 diabetes mellitus and non-alcoholic steatohepatitis. Curr. Opin. Investig. Drugs 2009, 10, 1049-1060. [CrossRef]

9. Sripetchwandee, J.; Chattipakorn, N.; Chattipakorn, S.C. Links Between Obesity-Induced Brain Insulin Resistance, Brain Mitochondrial Dysfunction, and Dementia. Front. Endocrinol. 2018, 9, 496. [CrossRef]

10. Arnold, S.E.; Arvanitakis, Z.; Macauley-Rambach, S.L.; Koenig, A.M.; Wang, H.Y.; Ahima, R.S.; Craft, S.; Gandy, S.; Buettner, C.; Stoeckel, L.E.; et al. Brain insulin resistance in type 2 diabetes and Alzheimer disease: Concepts and conundrums. Nat. Rev. Neurol. 2018, 14, 168-181. [CrossRef]

11. Heni, M.; Kullmann, S.; Preissl, H.; Fritsche, A.; Häring, H.U. Impaired insulin action in the human brain: Causes and metabolic consequences. Nat. Rev. Endocrinol. 2015, 11, 701-711. [CrossRef]

12. Blázquez, E.; Velázquez, E.; Hurtado-Carneiro, V.; Ruiz-Albusac, J.M. Insulin in the brain: Its pathophysiological implications for states related with central insulin resistance, type 2 diabetes and alzheimer's disease. Front. Endocrinol. 2014, 5, 161. [CrossRef]

13. Nelson, T.J.; Sun, M.K.; Hongpaisan, J.; Alkon, D.L. Insulin, PKC signaling pathways and synaptic remodeling during memory storage and neuronal repair. Eur. J. Pharmacol. 2008, 585, 76-87. [CrossRef] [PubMed]

14. Gray, S.M.; Meijer, R.I.; Barrett, E.J. Insulin regulates brain function, but how does it get there? Diabetes 2014, 63, 3992-3997. [CrossRef] [PubMed]

15. Frisardi, V.; Solfrizzi, V.; Seripa, D.; Capurso, C.; Santamato, A.; Sancarlo, D.; Vendemiale, G.; Pilotto, A.; Panza, F. Metabolic-cognitive syndrome: A cross-talk between metabolic syndrome and Alzheimer's disease. Ageing Res. Rev. 2010, 9, 399-417. [CrossRef]

16. Tong, M.; De La Monte, S.M. Mechanisms of ceramide-mediated neurodegeneration. J. Alzheimer's Dis. 2009, 16, 705-714. [CrossRef] [PubMed]

17. Butterfield, D.A.; Di Domenico, F.; Barone, E. Elevated risk of type 2 diabetes for development of Alzheimer disease: A key role for oxidative stress in brain. Biochim. Biophys. Acta 2014, 1842, 1693-1706. [CrossRef] [PubMed]

18. Whitmer, R.A. Type 2 diabetes and risk of cognitive impairment and dementia. Curr. Neurol. Neurosci. Rep. 2007, 7, 373-380. [CrossRef] [PubMed]

19. Maciejczyk, M.; Mikoluc, B.; Pietrucha, B.; Heropolitanska-Pliszka, E.; Pac, M.; Motkowski, R.; Car, H. Oxidative stress, mitochondrial abnormalities and antioxidant defense in Ataxia-telangiectasia, Bloom syndrome and Nijmegen breakage syndrome. Redox Biol. 2017, 11, 375-383. [CrossRef] [PubMed]

20. Ray, P.D.; Huang, B.W.; Tsuji, Y. Reactive oxygen species (ROS) homeostasis and redox regulation in cellular signaling. Cell Signal. 2012, 24, 981-990. [CrossRef] [PubMed]

21. Gandhi, S.; Abramov, A.Y. Mechanism of oxidative stress in neurodegeneration. Oxid. Med. Cell. Longev. 2012, 2012, 428010. [CrossRef] [PubMed]

22. Cobb, C.A.; Cole, M.P. Oxidative and nitrative stress in neurodegeneration. Neurobiol. Dis. 2015, 84, 4-21. [CrossRef]

23. Federico, A.; Cardaioli, E.; Da Pozzo, P.; Formichi, P.; Gallus, G.N.; Radi, E. Mitochondria, oxidative stress and neurodegeneration. J. Neurol. Sci. 2012. [CrossRef] [PubMed]

24. Zhao, W.; Chen, H.; Xu, H.; Moore, E.; Meiri, N.; Quon, M.J.; Alkon, D.L. Brain insulin receptors and spatial memory. Correlated changes in gene expression, tyrosine phosphorylation, and signaling molecules in the hippocampus of water maze trained rats. J. Biol. Chem. 1999. [CrossRef]

25. Schechter, R.; Whitmire, J.; Holtzclaw, L.; George, M.; Harlow, R.; Devaskar, S.U. Developmental regulation of insulin in the mammalian central nervous system. Brain Res. 1992. [CrossRef]

26. Banks, W.A.; Owen, J.B.; Erickson, M.A. Insulin in the brain: There and back again. Pharmacol. Ther. 2012, 136, 82-93. [CrossRef] [PubMed]

27. Kleinridders, A.; Ferris, H.A.; Cai, W.; Kahn, C.R. Insulin action in brain regulates systemic metabolism and brain function. Diabetes 2014, 63, 2232-2243. [CrossRef] [PubMed]

28. Sa-nguanmoo, P.; Tanajak, P.; Kerdphoo, S.; Satjaritanun, P.; Wang, X.; Liang, G.; Li, X.; Jiang, C.; Pratchayasakul, W.; Chattipakorn, N.; et al. FGF21 improves cognition by restored synaptic plasticity, dendritic spine density, brain mitochondrial function and cell apoptosis in obese-insulin resistant male rats. Horm. Behav. 2016. [CrossRef] 
29. Talbot, K.; Wang, H.Y.; Kazi, H.; Han, L.Y.; Bakshi, K.P.; Stucky, A.; Fuino, R.L.; Kawaguchi, K.R.; Samoyedny, A.J.; Wilson, R.S.; et al. Demonstrated brain insulin resistance in Alzheimer's disease patients is associated with IGF-1 resistance, IRS-1 dysregulation, and cognitive decline. J. Clin. Investig. 2012. [CrossRef]

30. Stockhorst, U.; De Fries, D.; Steingrueber, H.J.; Scherbaum, W.A. Insulin and the CNS: Effects on food intake, memory, and endocrine parameters and the role of intranasal insulin administration in humans. Physiol. Behav. 2004. [CrossRef]

31. Feldman, D.E. Synaptic Mechanisms for Plasticity in Neocortex. Annu. Rev. Neurosci. 2009. [CrossRef]

32. Song, I.; Huganir, R.L. Regulation of AMPA receptors during synaptic plasticity. Trends Neurosci. 2002. [CrossRef]

33. Zhao, W.Q.; Alkon, D.L. Role of insulin and insulin receptor in learning and memory. Mol. Cell. Endocrinol. 2001. [CrossRef]

34. Vannucci, S.J.; Koehler-Stec, E.M.; Li, K.; Reynolds, T.H.; Clark, R.; Simpson, I.A. GLUT4 glucose transporter expression in rodent brain: Effect of diabetes. Brain Res. 1998. [CrossRef]

35. Diggs-Andrews, K.A.; Zhang, X.; Song, Z.; Daphna-Iken, D.; Routh, V.H.; Fisher, S.J. Brain insulin action regulates hypothalamic glucose sensing and the counterregulatory response to hypoglycemia. Diabetes 2010. [CrossRef]

36. Reno, C.M.; Puente, E.C.; Sheng, Z.; Daphna-Iken, D.; Bree, A.J.; Routh, V.H.; Kahn, B.B.; Fisher, S.J. Brain GLUT4 knockout mice have impaired glucose tolerance, decreased insulin sensitivity, and impaired hypoglycemic counterregulation. Diabetes 2017. [CrossRef]

37. Scherer, T.; OHare, J.; Diggs-Andrews, K.; Schweiger, M.; Cheng, B.; Lindtner, C.; Zielinski, E.; Vempati, P.; Su, K.; Dighe, S.; et al. Brain insulin controls adipose tissue lipolysis and lipogenesis. Cell Metab. 2011. [CrossRef]

38. Holloway, G.P.; Han, X.X.; Jain, S.S.; Bonen, A.; Chabowski, A. Chronic muscle stimulation improves insulin sensitivity while increasing subcellular lipid droplets and reducing selected diacylglycerol and ceramide species in obese Zucker rats. Diabetologia 2014. [CrossRef]

39. Maciejczyk, M.; Matczuk, J.; Żendzian-Piotrowska, M.; Niklińska, W.; Fejfer, K.; Szarmach, I.; Ładny, J.R.; Zieniewska, I.; Zalewska, A. Eight-Week Consumption of High-Sucrose Diet Has a Pro-Oxidant Effect and Alters the Function of the Salivary Glands of Rats. Nutrients 2018, 10, 1530. [CrossRef]

40. Benedict, C.; Grillo, C.A. Insulin Resistance as a Therapeutic Target in the Treatment of Alzheimer's Disease: A State-of-the-Art Review. Front. Neurosci. 2018, 12, 215. [CrossRef]

41. Liu, Z.; Patil, I.Y.; Jiang, T.; Sancheti, H.; Walsh, J.P.; Stiles, B.L.; Yin, F.; Cadenas, E. High-fat diet induces hepatic insulin resistance and impairment of synaptic plasticity. PLoS ONE 2015, 10. [CrossRef]

42. Peng, Y.; Liu, J.; Shi, L.; Tang, Y.; Gao, D.; Long, J.; Liu, J. Mitochondrial dysfunction precedes depression of AMPK/AKT signaling in insulin resistance induced by high glucose in primary cortical neurons. J. Neurochem. 2016, 137, 701-713. [CrossRef]

43. Starr, J.M.; Wardlaw, J.M.; Ferguson, K.; MacLullich, A.; Deary, I.J.; Marshall, I. Increased blood-brain barrier permeability in type II diabetes demonstrated by gadolinium magnetic resonance imaging. J. Neurol. Neurosurg. Psychiatry 2003. [CrossRef]

44. Arnold, S.E.; Lucki, I.; Brookshire, B.R.; Carlson, G.C.; Browne, C.A.; Kazi, H.; Bang, S.; Choi, B.R.; Chen, Y.; McMullen, M.F.; et al. High fat diet produces brain insulin resistance, synaptodendritic abnormalities and altered behavior in mice. Neurobiol. Dis. 2014. [CrossRef]

45. De La Monte, S.M.; Lyn-Cook, L.E.; Lawton, M.; Tong, M.; Silbermann, E.; Longato, L.; Jiao, P.; Mark, P.; $\mathrm{Xu}, \mathrm{H} . ;$ Wands, J.R. Hepatic ceramide may mediate brain insulin resistance and neurodegeneration in type 2 diabetes and non-alcoholic steatohepatitis. Adv. Alzheimer's Dis. 2011, 1, 179-199. [CrossRef]

46. De la Monte, S.M.; Tong, M.; Wands, J.R. The 20-Year Voyage Aboard the Journal of Alzheimer's Disease: Docking at 'Type 3 Diabetes', Environmental/Exposure Factors, Pathogenic Mechanisms, and Potential Treatments. J. Alzheimer's Dis. 2018, 62, 1381-1390. [CrossRef]

47. Mencarelli, C.; Martinez-Martinez, P. Ceramide function in the brain: When a slight tilt is enough. Cell. Mol. Life Sci. 2013, 70, 181-203. [CrossRef]

48. Żendzian-Piotrowska, M.; Łukaszuk, B.; Maciejczyk, M.; Ostrowska, L.; Zalewska, A.; Chabowski, A.; Kurek, K. High-fat, high-protein, and high-carbohydrate diets affect sphingolipid profile in pancreatic steatosis in Wistar rats. Nutrition 2019, 60, 197-205. [CrossRef] 
49. He, X.; Huang, Y.; Li, B.; Gong, C.X.; Schuchman, E.H. Deregulation of sphingolipid metabolism in Alzheimer's disease. Neurobiol. Aging 2010. [CrossRef]

50. Chavez, J.A.; Summers, S.A. A ceramide-centric view of insulin resistance. Cell Metab. 2012, 15, 585-594. [CrossRef]

51. Summers, S.A. Ceramides in insulin resistance and lipotoxicity. Prog. Lipid Res. 2006, 45, 42-72. [CrossRef]

52. Haus, J.M.; Kashyap, S.R.; Kasumov, T.; Zhang, R.; Kelly, K.R.; Defronzo, R.A.; Kirwan, J.P. Plasma ceramides are elevated in obese subjects with type 2 diabetes and correlate with the severity of insulin resistance. Diabetes 2009, 58, 337-343. [CrossRef]

53. de la Monte, S.; Derdak, Z.; Wands, J.R. Alcohol, insulin resistance and the liver-brain axis. J. Gastroenterol. Hepatol. 2012. [CrossRef]

54. De La Monte, S.M.; Tong, M.; Nguyen, V.; Setshedi, M.; Longato, L.; Wands, J.R. Ceramide-mediated insulin resistance and impairment of cognitive-motor functions. J. Alzheimer's Dis. 2010. [CrossRef]

55. Cavaliere, G.; Viggiano, E.; Trinchese, G.; De Filippo, C.; Messina, A.; Monda, V.; Valenzano, A.; Cincione, R.I.; Zammit, C.; Cimmino, F.; et al. Long feeding high-fat diet induces hypothalamic oxidative stress and inflammation, and prolonged hypothalamic AMPK activation in rat animal model. Front. Physiol. 2018. [CrossRef]

56. Filippi, B.M.; Abraham, M.A.; Silva, P.N.; Rasti, M.; LaPierre, M.P.; Bauer, P.V.; Rocheleau, J.V.; Lam, T.K.T. Dynamin-Related Protein 1-Dependent Mitochondrial Fission Changes in the Dorsal Vagal Complex Regulate Insulin Action. Cell Rep. 2017. [CrossRef]

57. de la Monte, S.M.; Re, E.; Longato, L.; Tong, M. Dysfunctional pro-ceramide, ER stress, and insulin/IGF signaling networks with progression of Alzheimer's disease. J. Alzheimers Dis. 2012, 30 (Suppl. 2), S217-S229. [CrossRef]

58. De La Monte, S.M.; Tong, M. Brain metabolic dysfunction at the core of Alzheimer's disease. Biochem. Pharmacol. 2014, 88, 548-559. [CrossRef]

59. Talbot, K. Brain insulin resistance in Alzheimer's disease and its potential treatment with GLP-1 analogs. Neurodegener. Dis. Manag. 2014, 4, 31-40. [CrossRef]

60. Jazvinšćak Jembrek, M.; Hof, P.R.; Šimić, G. Ceramides in Alzheimer's Disease: Key Mediators of Neuronal Apoptosis Induced by Oxidative Stress and A $\beta$ Accumulation. Oxid. Med. Cell. Longev. 2015, 2015, 346783. [CrossRef]

61. De La Monte, S.M. Brain Insulin Resistance and Deficiency as Therapeutic Targets in Alzheimers Disease. Curr. Alzheimer Res. 2012, 9, 35-66. [CrossRef]

62. Arboleda, G.; Huang, T.J.; Waters, C.; Verkhratsky, A.; Fernyhough, P.; Gibson, R.M. Insulin-like growth factor-1-dependent maintenance of neuronal metabolism through the phosphatidylinositol 3-kinase-Akt pathway is inhibited by C 2-ceramide in CAD cells. Eur. J. Neurosci. 2007. [CrossRef]

63. Morales, A.; Lee, H.; Goñi, F.M.; Kolesnick, R.; Fernandez-Checa, J.C. Sphingolipids and cell death. Apoptosis 2007, 12, 923-939. [CrossRef]

64. Ganesan, V.; Perera, M.N.; Colombini, D.; Datskovskiy, D.; Chadha, K.; Colombini, M. Ceramide and activated Bax act synergistically to permeabilize the mitochondrial outer membrane. Apoptosis 2010. [CrossRef]

65. Jana, A.; Hogan, E.L.; Pahan, K. Ceramide and neurodegeneration: Susceptibility of neurons and oligodendrocytes to cell damage and death. J. Neurol. Sci. 2009, 278, 5-15. [CrossRef]

66. Arboleda, G.; Morales, L.C.; Benítez, B.; Arboleda, H. Regulation of ceramide-induced neuronal death: Cell metabolism meets neurodegeneration. Brain Res. Rev. 2009, 59, 333-346. [CrossRef]

67. De La Monte, S.M.; Wands, J.R. Alzheimer's disease is type 3 diabetes-evidence reviewed. J. Diabetes Sci. Technol. 2008, 2, 1101-1113. [CrossRef]

68. Craft, S. Insulin resistance syndrome and Alzheimer's disease: Age- and obesity-related effects on memory, amyloid, and inflammation. Neurobiol. Aging 2005, 26 (Suppl. 1), 65-69. [CrossRef]

69. Bosco, D.; Fava, A.; Plastino, M.; Montalcini, T.; Pujia, A. Possible implications of insulin resistance and glucose metabolism in Alzheimer's disease pathogenesis. J. Cell. Mol. Med. 2011, 15, 1807-1821. [CrossRef]

70. Steen, E.; Terry, B.M.; Rivera, E.J.; Cannon, J.L.; Neely, T.R.; Tavares, R.; Xu, X.J.; Wands, J.R.; de la Monte, S.M. Impaired insulin and insulin-like growth factor expression and signaling mechanisms in Alzheimer's disease-Is this type 3 diabetes? J. Alzheimers Dis. 2005, 7, 63-80. [CrossRef] 
71. Caselli, R.J.; Chen, K.; Lee, W.; Alexander, G.E.; Reiman, E.M. Correlating cerebral hypometabolism with future memory decline in subsequent converters to amnestic pre-mild cognitive impairment. Arch. Neurol. 2008. [CrossRef]

72. Langbaum, J.B.S.; Chen, K.; Caselli, R.J.; Lee, W.; Reschke, C.; Bandy, D.; Alexander, G.E.; Burns, C.M.; Kaszniak, A.W.; Reeder, S.A.; et al. Hypometabolism in Alzheimer-affected brain regions in cognitively healthy latino individuals carrying the apolipoprotein E $\varepsilon 4$ allele. Arch. Neurol. 2010. [CrossRef]

73. De La Monte, S.M. Contributions of brain insulin resistance and deficiency in amyloid-related neurodegeneration in alzheimers disease. Drugs 2012, 72, 49-66. [CrossRef]

74. Rivera, E.J.; Goldin, A.; Fulmer, N.; Tavares, R.; Wands, J.R.; De La Monte, S.M. Insulin and insulin-like growth factor expression and function deteriorate with progression of Alzheimer's disease: Link to brain reductions in acetylcholine. J. Alzheimer's Dis. 2005. [CrossRef]

75. Kahn, S.E.; Hull, R.L.; Utzschneider, K.M. Mechanisms linking obesity to insulin resistance and type 2 diabetes. Nature 2006, 444, 840-846. [CrossRef]

76. Bhat, R.; Xue, Y.; Berg, S.; Hellberg, S.; Ormö, M.; Nilsson, Y.; Radesäter, A.C.; Jerning, E.; Markgren, P.O.; Borgegård, T.; et al. Structural Insights and Biological Effects of Glycogen Synthase Kinase 3-specific Inhibitor AR-A014418. J. Biol. Chem. 2003. [CrossRef]

77. Morales, I.; Farías, G.; MacCioni, R.B. Neuroimmunomodulation in the pathogenesis of alzheimer's disease. NeuroImmunoModulation 2010, 17, 202-204. [CrossRef]

78. Gasparini, L.; Gouras, G.K.; Wang, R.; Gross, R.S.; Beal, M.F.; Greengard, P.; Xu, H. Stimulation of beta-amyloid precursor protein trafficking by insulin reduces intraneuronal beta-amyloid and requires mitogen-activated protein kinase signaling. J. Neurosci. 2001, 21, 2561-2570. [CrossRef]

79. Xie, L.; Helmerhorst, E.; Taddei, K.; Plewright, B.; Van Bronswijk, W.; Martins, R. Alzheimer's beta-amyloid peptides compete for insulin binding to the insulin receptor. J. Neurosci. 2002, 22, RC221. [CrossRef]

80. De la Monte, S.M. Type 3 diabetes is sporadic Alzheimer-s disease: Mini-review. Eur. Neuropsychopharmacol. 2014. [CrossRef]

81. Avgerinos, K.I.; Kalaitzidis, G.; Malli, A.; Kalaitzoglou, D.; Myserlis, P.G.; Lioutas, V.A. Intranasal insulin in Alzheimer's dementia or mild cognitive impairment: A systematic review. J. Neurol. 2018, 265, 1497-1510. [CrossRef]

82. Freiherr, J.; Hallschmid, M.; Frey, W.H.; Brünner, Y.F.; Chapman, C.D.; Hölscher, C.; Craft, S.; De Felice, F.G.; Benedict, C. Intranasal insulin as a treatment for alzheimer's disease: A review of basic research and clinical evidence. CNS Drugs 2013, 27, 505-514. [CrossRef]

83. Guo, Z.; Chen, Y.; Mao, Y.F.; Zheng, T.; Jiang, Y.; Yan, Y.; Yin, X.; Zhang, B. Long-term treatment with intranasal insulin ameliorates cognitive impairment, tau hyperphosphorylation, and microglial activation in a streptozotocin-induced Alzheimer's rat model. Sci. Rep. 2017. [CrossRef]

84. Craft, S.; Baker, L.D.; Montine, T.J.; Minoshima, S.; Watson, G.S.; Claxton, A.; Arbuckle, M.; Callaghan, M.; Tsai, E.; Plymate, S.R.; et al. Intranasal insulin therapy for Alzheimer disease and amnestic mild cognitive impairment: A pilot clinical trial. Arch. Neurol. 2012. [CrossRef]

85. Tangvarasittichai, S. Oxidative stress, insulin resistance, dyslipidemia and type 2 diabetes mellitus. World J. Diabetes 2015. [CrossRef]

86. Rains, J.L.; Jain, S.K. Oxidative stress, insulin signaling, and diabetes. Free Radic. Biol. Med. 2011, 50, 567-575. [CrossRef]

87. Choromańska, M.; Klimiuk, A.; Kostecka-Sochoń, P.; Wilczyńska, K.; Kwiatkowski, M.; Okuniewska, N.; Waszkiewicz, N.; Zalewska, A.; Maciejczyk, M. Antioxidant defence, oxidative stress and oxidative damage in saliva, plasma and erythrocytes of dementia patients. Can salivary AGE be a marker of dementia? Int. J. Mol. Sci. 2017, 18, 2205. [CrossRef]

88. Shukla, V.; Mishra, S.K.; Pant, H.C. Oxidative stress in neurodegeneration. Adv. Pharmacol. Sci. 2011. [CrossRef]

89. Borys, J.; Maciejczyk, M.; Antonowicz, B.; Krętowski, A.; Sidun, J.; Domel, E.; Dą̧rowski, J.R.; Ładny, J.R.; Morawska, K.; Zalewska, A. Glutathione Metabolism, Mitochondria Activity, and Nitrosative Stress in Patients Treated for Mandible Fractures. J. Clin. Med. 2019, 8, 127. [CrossRef]

90. Lushchak, V.I. Free radicals, reactive oxygen species, oxidative stress and its classification. Chem. Biol. Interact. 2014, 224c, 164-175. [CrossRef]

91. Valko, M.; Leibfritz, D.; Moncol, J.; Cronin, M.T.D.; Mazur, M.; Telser, J. Free radicals and antioxidants in normal physiological functions and human disease. Int. J. Biochem. Cell Biol. 2007, 39, 44-84. [CrossRef] 
92. Kołodziej, U.; Maciejczyk, M.; Miąsko, A.; Matczuk, J.; Knaś, M.; Żukowski, P.; Żendzian-Piotrowska, M.; Borys, J.; Zalewska, A. Oxidative Modification in the Salivary Glands of High Fat-Diet Induced Insulin Resistant Rats. Front. Physiol. 2017, 8, 20. [CrossRef] [PubMed]

93. Maciejczyk, M.; Żebrowska, E.; Zalewska, A.; Chabowski, A. Redox Balance, Antioxidant Defense, and Oxidative Damage in the Hypothalamus and Cerebral Cortex of Rats with High Fat Diet-Induced Insulin Resistance. Oxid. Med. Cell. Longev. 2018, 2018, 1-11. [CrossRef] [PubMed]

94. Żukowski, P.; Maciejczyk, M.; Matczuk, J.; Kurek, K.; Waszkiel, D.; Zendzian-Piotrowska, M.; Zalewska, A. Effect of N-Acetylcysteine on Antioxidant Defense, Oxidative Modification, and Salivary Gland Function in a Rat Model of Insulin Resistance. Oxid. Med. Cell. Longev. 2018, 2018. [CrossRef] [PubMed]

95. Champe, P.C.; Harvey, R.A. Biochemistry; J.B. Lippincott: Philadelphia, PA, USA, 1994; ISBN 0397510918.

96. Giacco, F.; Brownlee, M. Oxidative stress and diabetic complications. Circ. Res. 2010, 107, 1058-1070. [CrossRef] [PubMed]

97. Henriksen, E.J.; Diamond-Stanic, M.K.; Marchionne, E.M. Oxidative stress and the etiology of insulin resistance and type 2 diabetes. Free Radic. Biol. Med. 2011, 51, 993-999. [CrossRef] [PubMed]

98. FangFang; Li, H.; Qin, T.; Li, M.; Ma, S. Thymol improves high-fat diet-induced cognitive deficits in mice via ameliorating brain insulin resistance and upregulating NRF2/HO-1 pathway. Metab. Brain Dis. 2017, 32, 385-393. [CrossRef] [PubMed]

99. Kleinridders, A.; Cai, W.; Cappellucci, L.; Ghazarian, A.; Collins, W.R.; Vienberg, S.G.; Pothos, E.N.; Kahn, C.R. Insulin resistance in brain alters dopamine turnover and causes behavioral disorders. Proc. Natl. Acad. Sci. USA 2015. [CrossRef] [PubMed]

100. Wang, X.; Michaelis, E.K. Selective Neuronal Vulnerability to Oxidative Stress in the Brain. Front. Aging Neurosci. 2010, 2, 12. [CrossRef] [PubMed]

101. Cobley, J.N.; Fiorello, M.L.; Bailey, D.M. 13 reasons why the brain is susceptible to oxidative stress. Redox Biol. 2018, 15, 490-503. [CrossRef] [PubMed]

102. Verdile, G.; Keane, K.N.; Cruzat, V.F.; Medic, S.; Sabale, M.; Rowles, J.; Wijesekara, N.; Martins, R.N.; Fraser, P.E.; Newsholme, P. Inflammation and Oxidative Stress: The Molecular Connectivity between Insulin Resistance, Obesity, and Alzheimer's Disease. Mediat. Inflamm. 2015, 2015, 105828. [CrossRef] [PubMed]

103. Pipatpiboon, N.; Pratchayasakul, W.; Chattipakorn, N.; Chattipakorn, S.C. PPAR $\gamma$ agonist improves neuronal insulin receptor function in hippocampus and brain mitochondria function in rats with insulin resistance induced by long term high-fat diets. Endocrinology 2012. [CrossRef] [PubMed]

104. Amin, K.A.; Kamel, H.H.; Abd Eltawab, M.A. The relation of high fat diet, metabolic disturbances and brain oxidative dysfunction: Modulation by hydroxy citric acid. Lipids Health Dis. 2011. [CrossRef]

105. Baquedano, E.; Burgos-Ramos, E.; Canelles, S.; González-Rodríguez, A.; Chowen, J.A.; Argente, J.; Barrios, V.; Valverde, A.M.; Frago, L.M. Increased oxidative stress and apoptosis in the hypothalamus of diabetic male mice in the insulin receptor substrate-2 knockout model. Dis. Model. Mech. 2016. [CrossRef] [PubMed]

106. Maciejczyk, M.; Szulimowska, J.; Skutnik, A.; Taranta-Janusz, K.; Wasilewska, A.; Wiśniewska, N.; Zalewska, A. Salivary Biomarkers of Oxidative Stress in Children with Chronic Kidney Disease. J. Clin. Med. 2018, 7, 209. [CrossRef] [PubMed]

107. Potukuchi, A.; Addepally, U.; Sindhu, K.; Manchala, R. Increased total DNA damage and oxidative stress in brain are associated with decreased longevity in high sucrose diet fed WNIN/Gr-Ob obese rats. Nutr. Neurosci. 2018, 21, 648-656. [CrossRef] [PubMed]

108. Kim, J.M.; Park, C.H.; Park, S.K.; Seung, T.W.; Kang, J.Y.; Ha, J.S.; Lee, D.S.; Lee, U.; Kim, D.-O.; Heo, H.J. Ginsenoside Re Ameliorates Brain Insulin Resistance and Cognitive Dysfunction in High Fat Diet-Induced C57BL/6 Mice. J. Agric. Food Chem. 2017, 65, 2719-2729. [CrossRef] [PubMed]

109. Koga, M.; Serritella, A.V.; Messmer, M.M.; Hayashi-Takagi, A.; Hester, L.D.; Snyder, S.H.; Sawa, A.; Sedlak, T.W. Glutathione is a physiologic reservoir of neuronal glutamate. Biochem. Biophys. Res. Commun. 2011, 409, 596-602. [CrossRef]

110. Schulz, J.B.; Lindenau, J.; Seyfried, J.; Dichgans, J. Glutathione, oxidative stress and neurodegeneration. Eur. J. Biochem. 2000, 267, 4904-4911. [CrossRef]

111. Aoyama, K.; Nakaki, T. Impaired glutathione synthesis in neurodegeneration. Int. J. Mol. Sci. 2013, 14, 21021-21044. [CrossRef]

112. Johnson, W.M.; Wilson-Delfosse, A.L.; Mieyal, J.J. Dysregulation of glutathione homeostasis in neurodegenerative diseases. Nutrients 2012, 4, 1399-1440. [CrossRef] 
113. Dringen, R.; Hirrlinger, J. Glutathione pathways in the brain. Biol. Chem. 2003, 384, 505-516. [CrossRef] [PubMed]

114. Żebrowska-Gamdzyk, M.; Maciejczyk, M.; Zalewska, A.; Guzińska-Ustymowicz, K.; Tokajuk, A.; Car, H. Whey Protein Concentrate WPC-80 Intensifies Glycoconjugate Catabolism and Induces Oxidative Stress in the Liver of Rats. Nutrients 2018, 10, 1178. [CrossRef] [PubMed]

115. Münch, G.; Schinzel, R.; Loske, C.; Wong, A.; Durany, N.; Li, J.J.; Vlassara, H.; Smith, M.A.; Perry, G.; Riederer, P. Alzheimer's disease-Synergistic effects of glucose deficit, oxidative stress and advanced glycation endproducts. J. Neural Transm. 1998. [CrossRef] [PubMed]

116. Ott, C.; Jacobs, K.; Haucke, E.; Navarrete Santos, A.; Grune, T.; Simm, A. Role of advanced glycation end products in cellular signaling. Redox Biol. 2014, 2, 411-429. [CrossRef] [PubMed]

117. Cutler, R.G.; Kelly, J.; Storie, K.; Pedersen, W.A.; Tammara, A.; Hatanpaa, K.; Troncoso, J.C.; Mattson, M.P. Involvement of oxidative stress-induced abnormalities in ceramide and cholesterol metabolism in brain aging and Alzheimer's disease. Proc. Natl. Acad. Sci. USA 2004. [CrossRef]

118. Yamagishi, S. ichi Diabetes and advanced glycation end products. In Diabetes and Aging-Related Complications; Humana Press: Totowa, NJ, USA, 2017; ISBN 9789811043765.

119. Srikanth, V.; Maczurek, A.; Phan, T.; Steele, M.; Westcott, B.; Juskiw, D.; Münch, G. Advanced glycation endproducts and their receptor RAGE in Alzheimer's disease. Neurobiol. Aging 2011, 32, 763-777. [CrossRef]

120. Song, F.; Del Pozo, C.H.; Rosario, R.; Zou, Y.S.; Ananthakrishnan, R.; Xu, X.; Patel, P.R.; Benoit, V.M.; Yan, S.F.; $\mathrm{Li}, \mathrm{H}$;; et al. RAGE regulates the metabolic and inflammatory response to high-fat feeding in mice. Diabetes 2014. [CrossRef] [PubMed]

121. Wautier, M.-P.; Chappey, O.; Corda, S.; Stern, D.M.; Schmidt, A.M.; Wautier, J.-L. Activation of NADPH oxidase by AGE links oxidant stress to altered gene expression via RAGE. Am. J. Physiol. Metab. 2001. [CrossRef] [PubMed]

122. Qin, L.; Liu, Y.; Hong, J.S.; Crews, F.T. NADPH oxidase and aging drive microglial activation, oxidative stress, and dopaminergic neurodegeneration following systemic LPS administration. Glia 2013. [CrossRef] [PubMed]

123. Zhang, X.; Dong, F.; Ren, J.; Driscoll, M.J.; Culver, B. High dietary fat induces NADPH oxidase-associated oxidative stress and inflammation in rat cerebral cortex. Exp. Neurol. 2005. [CrossRef] [PubMed]

124. Juranek, J.; Ray, R.; Banach, M.; Rai, V. Receptor for advanced glycation end-products in neurodegenerative diseases. Rev. Neurosci. 2015, 26, 691-698. [CrossRef]

125. Villa, R.F.; Ferrari, F.; Gorini, A. Energy metabolism of rat cerebral cortex, hypothalamus and hypophysis during ageing. Neuroscience 2012, 227, 55-66. [CrossRef] [PubMed]

126. Kaur, P.; Aschner, M.; Syversen, T. Role of glutathione in determining the differential sensitivity between the cortical and cerebellar regions towards mercury-induced oxidative stress. Toxicology 2007, 230, 164-177. [CrossRef] [PubMed]

127. Nagle, C.A.; Klett, E.L.; Coleman, R.A. Hepatic triacylglycerol accumulation and insulin resistance. J. Lipid Res. 2009. [CrossRef] [PubMed]

128. Kahn, S.E.; Cooper, M.E.; Del Prato, S. Pathophysiology and treatment of type 2 diabetes: Perspectives on the past, present, and future. Lancet 2014, 383, 1068-1083. [CrossRef]

129. Aguirre, V.; Uchida, T.; Yenush, L.; Davis, R.; White, M.F. The c-Jun NH2-terminal kinase promotes insulin resistance during association with insulin receptor substrate-1 and phosphorylation of Ser307. J. Biol. Chem. 2000. [CrossRef]

130. Osborn, O.; Olefsky, J.M. The cellular and signaling networks linking the immune system and metabolism in disease. Nat. Med. 2012, 18, 363-374. [CrossRef]

131. Boucher, J.; Kleinridders, A.; Ronald Kahn, C. Insulin receptor signaling in normal and insulin-resistant states. Cold Spring Harb. Perspect. Biol. 2014. [CrossRef]

132. Luo, X.; Wu, J.; Jing, S.; Yan, L.-J. Hyperglycemic Stress and Carbon Stress in Diabetic Glucotoxicity. Aging Dis. 2016, 7, 90-110. [CrossRef]

133. Del Prato, S. Role of glucotoxicity and lipotoxicity in the pathophysiology of Type 2 diabetes mellitus and emerging treatment strategies. Diabet. Med. 2009, 18, 363-374. [CrossRef]

134. Szendroedi, J.; Phielix, E.; Roden, M. The role of mitochondria in insulin resistance and type 2 diabetes mellitus. Nat. Rev. Endocrinol. 2012, 8, 83-103. [CrossRef] [PubMed] 
135. Koliaki, C.; Roden, M. Alterations of Mitochondrial Function and Insulin Sensitivity in Human Obesity and Diabetes Mellitus. Annu. Rev. Nutr. 2016, 36, 337-367. [CrossRef] [PubMed]

136. Cheng, Z.; Tseng, Y.; White, M.F. Insulin signaling meets mitochondria in metabolism. Trends Endocrinol. Metab. 2010, 21, 589-598. [CrossRef] [PubMed]

137. Martin, S.D.; McGee, S.L. The role of mitochondria in the aetiology of insulin resistance and type 2 diabetes. Biochim. Biophys. Acta Gen. Subj. 2014, 1840, 1303-1312. [CrossRef] [PubMed]

138. Olefsky, J.M.; Glass, C.K. Macrophages, Inflammation, and Insulin Resistance. Annu. Rev. Physiol. 2010. [CrossRef] [PubMed]

139. Cai, D.; Yuan, M.; Frantz, D.F.; Melendez, P.A.; Hansen, L.; Lee, J.; Shoelson, S.E. Local and systemic insulin resistance resulting from hepatic activation of IKK- $\beta$ and NF-KB. Nat. Med. 2005. [CrossRef] [PubMed]

140. Arkan, M.C.; Hevener, A.L.; Greten, F.R.; Maeda, S.; Li, Z.W.; Long, J.M.; Wynshaw-Boris, A.; Poli, G.; Olefsky, J.; Karin, M. IKK- $\beta$ links inflammation to obesity-induced insulin resistance. Nat. Med. 2005. [CrossRef]

141. Morgan, M.J.; Liu, Z.G. Crosstalk of reactive oxygen species and NF-кB signaling. Cell Res. 2011, 21, $103-115$. [CrossRef]

142. Kopitar-Jerala, N. Innate Immune Response in Brain, NF-Kappa B Signaling and Cystatins. Front. Mol. Neurosci. 2015. [CrossRef]

143. Sartorius, T.; Peter, A.; Schulz, N.; Drescher, A.; Bergheim, I.; MacHann, J.; Schick, F.; Siegel-Axel, D.; Schürmann, A.; Weigert, C.; et al. Cinnamon extract improves insulin sensitivity in the brain and lowers liver fat in mouse models of obesity. PLoS ONE 2014. [CrossRef]

144. Yabu, T.; Shiba, H.; Shibasaki, Y.; Nakanishi, T.; Imamura, S.; Touhata, K.; Yamashita, M. Stress-induced ceramide generation and apoptosis via the phosphorylation and activation of nSMase1 by JNK signaling. Cell Death Differ. 2015. [CrossRef] [PubMed]

145. Andrieu-Abadie, N.; Gouazé, V.; Salvayre, R.; Levade, T. Ceramide in apoptosis signaling: Relationship with oxidative stress. Free Radic. Biol. Med. 2001, 31, 717-728. [CrossRef]

146. Ahmad, W.; Ijaz, B.; Shabbiri, K.; Ahmed, F.; Rehman, S. Oxidative toxicity in diabetes and Alzheimer's disease: Mechanisms behind ROS/RNS generation. J. Biomed. Sci. 2017, 24, 76. [CrossRef]

147. Ho, L.; Qin, W.; Pompl, P.N.; Xiang, Z.; Wang, J.; Zhao, Z.; Peng, Y.; Cambareri, G.; Rocher, A.; Mobbs, C.V.; et al. Diet-induced insulin resistance promotes amyloidosis in a transgenic mouse model of Alzheimer's disease. FASEB J. 2004. [CrossRef] [PubMed]

148. Willette, A.A.; Johnson, S.C.; Birdsill, A.C.; Sager, M.A.; Christian, B.; Baker, L.D.; Craft, S.; Oh, J.; Statz, E.; Hermann, B.P.; et al. Insulin resistance predicts brain amyloid deposition in late middle-aged adults. Alzheimer's Dement. 2015. [CrossRef] [PubMed]

149. Bruce-Keller, A.J.; White, C.L.; Gupta, S.; Knight, A.G.; Pistell, P.J.; Ingram, D.K.; Morrison, C.D.; Keller, J.N. NOX activity in brain aging: Exacerbation by high fat diet. Free Radic. Biol. Med. 2010. [CrossRef] [PubMed]

150. Pepping, J.K.; Freeman, L.R.; Gupta, S.; Keller, J.N.; Bruce-Keller, A.J. NOX2 deficiency attenuates markers of adiposopathy and brain injury induced by high-fat diet. Am. J. Physiol. Metab. 2013. [CrossRef]

151. Drougard, A.; Fournel, A.; Valet, P.; Knauf, C. Impact of hypothalamic reactive oxygen species in the regulation of energy metabolism and food intake. Front. Neurosci. 2015, 9, 56. [CrossRef]

152. Chawla, A.; Nguyen, K.D.; Goh, Y.P. Macrophage-mediated inflammation in metabolic disease. Nat. Rev. Immunol. 2011, 11, 738-749. [CrossRef]

153. Biessels, G.J.; Strachan, M.W.J.; Visseren, F.L.J.; Kappelle, L.J.; Whitmer, R.A. Dementia and cognitive decline in type 2 diabetes and prediabetic stages: Towards targeted interventions. Lancet Diabetes Endocrinol. 2014, 2, 246-255. [CrossRef]

154. Biessels, G.J.; Reagan, L.P. Hippocampal insulin resistance and cognitive dysfunction. Nat. Rev. Neurosci. 2015, 16, 660-671. [CrossRef]

155. Chen, L.; Chen, R.; Wang, H.; Liang, F. Mechanisms Linking Inflammation to Insulin Resistance. Int. J. Endocrinol. 2015, 2015, 508409. [CrossRef]

156. Zhou, H.; Liu, X.; Liu, L.; Yang, Z.; Zhang, S.; Tang, M.; Tang, Y.; Dong, Q.; Hu, R. Oxidative stress and apoptosis of human brain microvascular endothelial cells induced by free fatty acids. J. Int. Med. Res. 2009. [CrossRef] 
157. Diaz, B.; Fuentes-Mera, L.; Tovar, A.; Montiel, T.; Massieu, L.; Martínez-Rodríguez, H.G.; Camacho, A. Saturated lipids decrease mitofusin 2 leading to endoplasmic reticulum stress activation and insulin resistance in hypothalamic cells. Brain Res. 2015. [CrossRef] [PubMed]

158. Zhou, H.G.; Liu, L.; Zhang, Y.; Huang, Y.Y.; Tao, Y.H.; Zhang, S.; Su, J.J.; Tang, Y.P.; Guo, Z.L.; Hu, R.M.; et al. Glutathione prevents free fatty acids-induced oxidative stress and apoptosis in human brain vascular endothelial cells through akt pathway. CNS Neurosci. Ther. 2013. [CrossRef] [PubMed]

159. Beaulieu, E.; Ioffe, J.; Watson, S.N.; Hermann, P.M.; Wildering, W.C. Oxidative-stress induced increase in circulating fatty acids does not contribute to phospholipase A2-dependent appetitive long-term memory failure in the pond snail Lymnaea stagnalis. BMC Neurosci. 2014. [CrossRef]

160. Montgomery, M.K.; Turner, N. Mitochondrial dysfunction and insulin resistance: An update. Endocr. Connect. 2014. [CrossRef] [PubMed]

161. Kim, J.A.; Wei, Y.; Sowers, J.R. Role of mitochondrial dysfunction in insulin resistance. Circ. Res. 2008, 102, 401-414. [CrossRef]

162. Raza, H.; John, A.; Howarth, F.C. Increased oxidative stress and mitochondrial dysfunction in zucker diabetic rat liver and brain. Cell. Physiol. Biochem. 2015. [CrossRef]

163. Wang, D.; Yan, J.; Chen, J.; Wu, W.; Zhu, X.; Wang, Y. Naringin Improves Neuronal Insulin Signaling, Brain Mitochondrial Function, and Cognitive Function in High-Fat Diet-Induced Obese Mice. Cell. Mol. Neurobiol. 2015. [CrossRef]

164. Porter, D.; Faivre, E.; Flatt, P.R.; Hölscher, C.; Gault, V.A. Actions of incretin metabolites on locomotor activity, cognitive function and in vivo hippocampal synaptic plasticity in high fat fed mice. Peptides 2012. [CrossRef] [PubMed]

165. Dragicevic, N.; Mamcarz, M.; Zhu, Y.; Buzzeo, R.; Tan, J.; Arendash, G.W.; Bradshaw, P.C. Mitochondrial amyloid-beta levels are associated with the extent of mitochondrial dysfunction in different brain regions and the degree of cognitive impairment in Alzheimer's transgenic mice. J. Alzheimers Dis. 2010. [CrossRef] [PubMed]

166. Baek, S.H.; Park, S.J.; Jeong, J.I.; Kim, S.H.; Han, J.; Kyung, J.W.; Baik, S.-H.; Choi, Y.; Choi, B.Y.; Park, J.S.; et al. Inhibition of Drp1 Ameliorates Synaptic Depression, A $\beta$ Deposition, and Cognitive Impairment in an Alzheimer's Disease Model. J. Neurosci. 2017. [CrossRef] [PubMed]

167. Chunchai, T.; Samniang, B.; Sripetchwandee, J.; Pintana, H.; Pongkan, W.; Kumfu, S.; Shinlapawittayatorn, K.; Kenknight, B.H.; Chattipakorn, N.; Chattipakorn, S.C. Vagus Nerve Stimulation Exerts the Neuroprotective Effects in Obese-Insulin Resistant Rats, Leading to the Improvement of Cognitive Function. Sci. Rep. 2016. [CrossRef]

168. Sun, Z.; Zhan, L.; Liang, L.; Sui, H.; Zheng, L.; Sun, X.; Xie, W. ZiBu PiYin recipe prevents diabetes-associated cognitive decline in rats: Possible involvement of ameliorating mitochondrial dysfunction, insulin resistance pathway and histopathological changes. BMC Complement. Altern. Med. 2016. [CrossRef] [PubMed]

169. Kothari, V.; Luo, Y.; Tornabene, T.; O’Neill, A.M.; Greene, M.W.; Geetha, T.; Babu, J.R. High fat diet induces brain insulin resistance and cognitive impairment in mice. Biochim. Biophys. Acta Mol. Basis Dis. 2017. [CrossRef] [PubMed]

170. Palleria, C.; Leporini, C.; Maida, F.; Succurro, E.; De Sarro, G.; Arturi, F.; Russo, E. Potential effects of current drug therapies on cognitive impairment in patients with type 2 diabetes. Front. Neuroendocrinol. 2016, 42, 76-92. [CrossRef] [PubMed]

171. Pintana, H.; Tanajak, P.; Pratchayasakul, W.; Sa-Nguanmoo, P.; Chunchai, T.; Satjaritanun, P.; Leelarphat, L.; Chattipakorn, N.; Chattipakorn, S.C. Energy restriction combined with dipeptidyl peptidase-4 inhibitor exerts neuroprotection in obese male rats. Br. J. Nutr. 2016. [CrossRef]

172. Feng, Y.; Wang, X. Antioxidant therapies for Alzheimer's disease. Oxid. Med. Cell. Longev. 2012, $2012,472932$. [CrossRef]

173. Morley, J.E.; Farr, S.A.; Nguyen, A.D. Alzheimer Disease. Clin. Geriatr. Med. 2018, 34, 591-601. [CrossRef]

174. Mecocci, P.; Polidori, M.C. Antioxidant clinical trials in mild cognitive impairment and Alzheimer's disease. Biochim. Biophys. Acta Mol. Basis Dis. 2012, 1822, 631-638. [CrossRef] [PubMed]

(C) 2019 by the authors. Licensee MDPI, Basel, Switzerland. This article is an open access article distributed under the terms and conditions of the Creative Commons Attribution (CC BY) license (http:/ / creativecommons.org/licenses/by/4.0/). 